\title{
The Culture of Military School: The Example of the Dr. Franjo Tudjman Croatian Defense Academy
}

\section{Andrija Kozina}

Croatian Military Academy "Dr. Franjo Tudjman," https://vojni.unizg.hr/en

\begin{abstract}
Culture is defined in various ways. It often depends on an individual's experiences, the associated era, and societal norms and values. The various definitions indicate that culture is a contextually dependent concept. It is something by which the identity of a person, group, community, minority, organization, or nation can be recognized. Schools, as special educational institutions, have their own specific cultures. Each school's culture may be defined as its way of life and work, the influence of tradition, and the behavior of those attending which includes the teachers and all of its employees. Military organizations, which are some of the oldest and most prominent institutions, are specific working environments with a distinctive culture. Joining the armed forces involves giving up part of one's private life in order to become a soldier, a noncommissioned officer (NCO) or an officer. When a person enters a military school system, significant life changes occur, with the acceptance of different forms of personal, social, and professional activities. This article analyzes the Dr. Franjo Tuđman Croatian Defense Academy education system to identify the distinctive characteristics of a military school culture.
\end{abstract}

Keywords: culture, taxonomy, hierarchical form, military organization, school life, subculture, university study programs.

\section{Introduction}

If we observe soldiers, we notice that they behave according to rules. They know how to use their personal weapons, how to protect themselves, disguise themselves, receive orders from their superiors, perform the tasks assigned to them, and report on their performance. Most of these requirements stem from a gen- 
eral understanding of the organizational culture and the mission, including the social standards and relationships related to serving in the military and obeying orders.

Every organization relies and depends on its traditions and its environment. The longer the tradition, the more obvious and recognizable the culture is, and it is easier to define the values it promotes. Many factors, such as history, religion, ethnic identity, language, and nationality, create a culture. It develops in response to various pressures and influences; it is learned through socialization and is not inherited. ${ }^{1,2}$ Briefly, it promotes values and provides a lens through which its members can see and understand the world.

Culture, in military organizations, has a specific character and it differs from other cultures in terms of its philosophy, approach, and requirements. As a fundamental part of the education of future members through their curriculum outcomes, requirements, methods, content, and education levels, military schools must produce cadre that are capable, prepared and willing to fulfill their commanding officers' tasks. Here the special character of military schools differs from other schools that nurture the development of shared constructive action, critical thought, elimination or acceptance of imposed authority, questioning, and all the other special characteristics stemming from a student-centered philosophy. Of course, it cannot be said that military schools seek to avoid the development of these behaviors and thought, and they certainly do work to integrate them, but with a distinctive respect for the clear structure and the specific nature of the military ethos.

The development and reconciliation of these differences is the goal of all employees of military schools. As well as accepting the explicit requirements of their work, they must also, by their own example and implicit pedagogy, promote the fundamental values of the organization and thereby have a positive effect on the development of the school's unique culture. Therefore, it is extremely important to recognize, study, research, and improve the culture of military schools and their hidden, formal, and informal curriculum.

\section{The Definition of 'Culture'}

Culture (Lat: cultura, pres. verb. colere; to process, take care of, guard, nurture) is a human attribute. According to one definition, culture comprises the customs, ideas, beliefs, etc., of a specific society or social group. Tylor ${ }^{3}$ defines culture as:

1 Mary L. Connerley and Paul B. Pedersen, Leadership in a Diverse and Multicultural Environment: Developing Awareness, Knowledge, and Skills (Thousand Oaks, CA: Sage Publications, 2005).

2 Larry A. Samovar, Richard E. Porter, Edwin R. McDaniel, and Carolyn Sexton Roy, Communication Between Cultures, 9th ed. (Boston, MA: Cengage Learning, 2017).

3 Sir Edward Burnett Tylor (1832-1917) is a founder of modern anthropology and one of the first scientists to use the term culture in the universal and human sense. 
“(...) that complex whole which includes knowledge, beliefs, arts, morals, law, customs, and any other capabilities and habits acquired by [a human] as a member of society." ${ }^{4}$ Culture is defined in various ways, depending on an individual's perspective, the historical era, and the nature of one's society. The different definitions show that culture is difficult to explain, but according to the most general definition, it is what people have made of themselves and the world, something by which we are able to recognize the identity of a person, group, community, minority, nation or people; however, one culture can exist independently of other cultures. To comprehend and understand any culture, four essential components must be considered: political system, economy, social institutions (banks, school system, educational level, security forces, labor unions, all the way to football clubs), and culture. ${ }^{5}$

Cultural encounters occur daily, despite occasional differences in non-verbal communication (expressions of anger, contempt, disgust, fear, happiness, sadness, etc.). Learning about other cultures helps to reduce the inappropriate use of these expressions. In such communication, every culture presents, verifies, confirms, and develops itself. "Therefore, culture represents the framework of its identity, the framework of a person's identity, whereby various symbolic elements from language to social customs serve as markers of the special character, that is, the boundaries of group membership." ${ }^{6}$ Culture is always expressed when it encounters another culture or something different, and it is present and visible in almost all aspects of society, for instance, youth culture, leadership culture, pop culture, religious culture, ethnic culture, health culture, etc.

Hofstede defines culture synthetically, stating: “(...) the collective programming of the mind which distinguishes the members of one group or category of people from another." 7 Culture, in the wider sense, is also not easy to define, because it is affected by the principles, beliefs, and values that determine perception, attitudes, expectation, interactive communication, and forms of behavior. Eagleton states that culture implies a dialectical relationship between the artificial and the natural, actually everything that a person does in relation to the world and what the world does in relation to a person. ${ }^{8}$ Man lives in nature and with nature, and from the very outset tries to shape it according to his needs, that is, to create some form of culture. Cifrić points out that culture appeared as

4 Edward Burnett Tylor, Primitive Culture Researches into the development of Mythology, Philosophy, Religion, Art, and Custom, $4^{\text {th }}$ ed., vol. I (London: John Murray, 1920), p. 1.

5 Casey Haskins, "A Practical Approach to Cultural Insight," Military Review 40, no.5 (September-October 2010): 79-87, quote on pp. 81-82.

6 Stjepan Jagić and Marko Vučetić, "Globalization Processes and Culture," Acta ladertina 9, no. 1 (2013): 15-24, - in Croatian, quote on p. 20.

7 Geert Hofstede, "Identifying Organizational Subcultures: An Empirical Approach," Journal of Management Studies 35, no. 1 (1998): 1-12, quote on p. 2.

8 Terry Eagleton, The Idea of Culture (Hoboken, NJ: Blackwell Publisher, 2000). 
a product. It is produced and 'lived' according to its response to society's physical and spiritual needs. It may be said that culture is everything that man has produced and that it is in fact, somewhat different from nature. ${ }^{9}$ It links the tasks, standards, and values, which society has agreed on and accepted, into a whole. Biloslavo and co-authors attempted to explain culture using an example. ${ }^{10}$ If one compares culture to a tree, the roots are the basic habits which people have acquired and which are passed on from generation to generation, the trunk are values and assets, and comprise adopted forms of behavior, and the visible forms are the external parts of the tree. One of the most acceptable and simplest definitions of culture states that it is "(...) the collection of shared convictions, values and presumptions of a specific group of people, who learn from one another and teach others that their convictions, values, and attitudes are correct." 11 Therefore, culture is the sum of human activity that is taught and passed on from generation to generation and which develops over the course of time.

Each person reflects and expresses his or her own culture. Culture directly affects the quality of a person's life and people influence culture development through their work. Unfortunately, the environment, but also each one's personal equation, may have a negative effect on society if that person does not want to adjust to the environment in which they live, or the culture and society which surrounds them, whereby they seek to influence the freedom of others or the legal order. Then, undesirable forms of behavior by individuals occurs, seen in intolerance and bigoted attitudes towards those who do not fit into their personal view of a community's cultural identity. Society is a complex network in which different interest groups exist, with their own specific cultures, and they all promote their own lifestyle and work ethic in accordance with their own philosophies.

Wunderle developed a three-level cultural taxonomy: cultural influences, cultural variations, and cultural manifestations (Figure 1). ${ }^{12}$ According to him, to increase cultural awareness, it is necessary to understand all three components:

- Cultural influences are major social or institutional factors (heritage, religion, traditions, and language) that bind people together. Of import-

9 Ivan Cifrić, “Life Within the Limits of Culture," Časopis za Filozofiju 6, no. 12 (2009): 69-83, quote on p. 70.

10 Roberto Biloslavo, J. Kovač, M. Markič, and A. Ježovnik, Strateški management in management spreminjanja [Strategic Management and Change Management] (Koper, Slovenia: Fakulteta za management, 2006).

11 Mai Moua, Culturally Intelligent Leadership, Leading Through Intercultural Interactions (New York: Business Expert Press, 2010), quote on p. 15.

12 William D. Wunderle, Through the Lens of Cultural Awareness: A Primer for US Armed Forces Deploying to Arab and Middle Eastern Countries (Washington DC: U.S. Government Printing Office, 2006), pp. 12-13. 
ance is a culture's heritage or history which can be critical in defining the culture's ethnic and national identity.

- Cultural variations are styles of behavior, values, and ways of thinking that are common to a culture. They consist of the language, social rules, customs, structures, and institutions of a given culture. Values are principles that members of a culture use to evaluate alternatives or consequences in decision making. Ways of thinking or cognition refer to preference-based strategies and processes used in decision making, perception, and knowledge representation of a given culture.

- Cultural manifestations are the concrete displays of a culture's thought and behavior, related to negotiation styles, willingness to compromise, and embracing of risk.

Wunderle also believes that the cultural taxonomy helps the American (and any other) military, involved in global peace-keeping operations, to understand the key features of the various cultures that are encountered. With an understanding of cultural taxonomy, members who are conducting an operation can cope more easily in situations on the ground, and thereby also increase the effectiveness of their work.

Military organizations are a cultural group. Members of military organizations live in line with their values. The structure of their daily activities aligns with military life. Early rising, physical exercise, shared meals, line-up (formations), strict respect for the prescribed working hours, regular reporting etc., all develop and

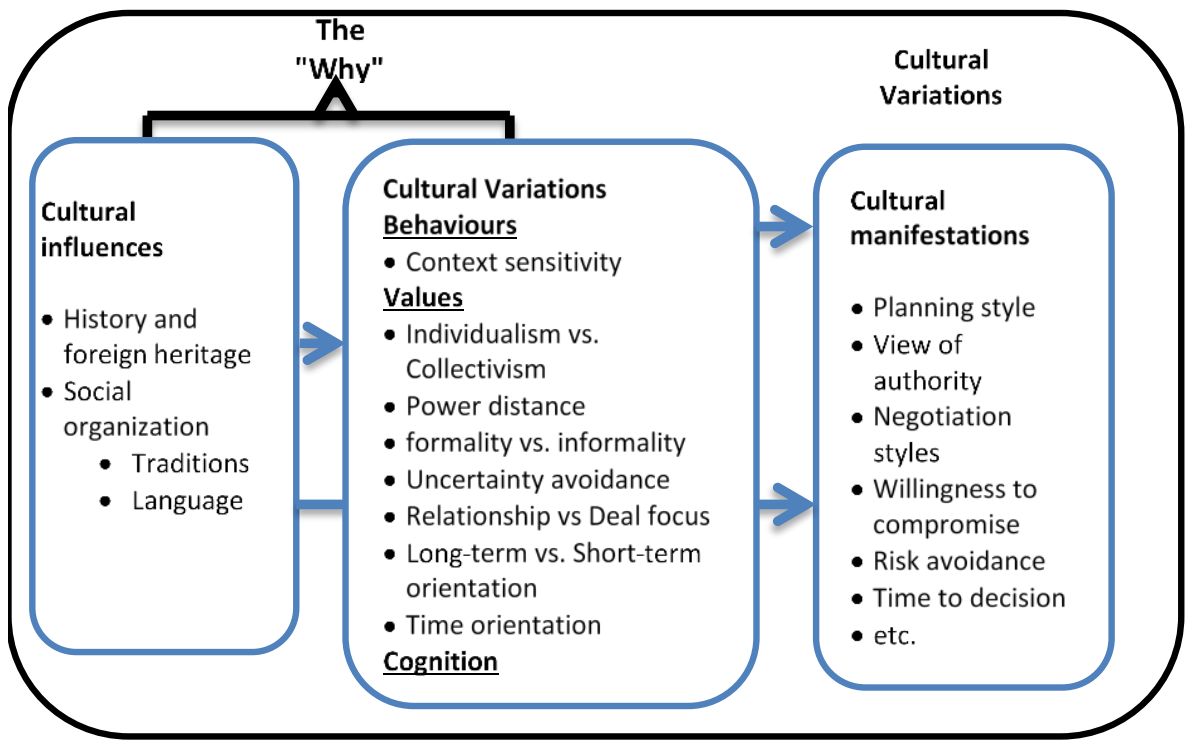

Figure 1: Taxonomy of Culture (Source: Wunderle, 2006). 
strengthen the influence of military culture on the formation of the soldier's attitudes and daily lives. In the army, a unit's commander has a major influence on cultural development. The commander's contribution to the creation of a positive climate reflects his personal behavior, through which he demonstrates the unit's competence and fundamental values, convictions, and presumptions. Therefore, if the commanding officer does not demonstrate the values of the armed forces of the state, members who are dedicated to that culture will not accept the commander as a legitimate authority, ${ }^{13}$ especially if his actions contradict the cultural values, convictions, and laws that they have already adopted.

\section{The Culture of a Military Organization}

The United States armed forces handbook describes culture as:

- " "(..) a web of meaning shared by members of a particular society or group within society;

- A system of shared beliefs, values, customs, behaviors, and artifacts that members of a society use to cope with their world and with one another;

- Learned, through a process called enculturation;

- Shared by members of society; there is no "culture of one";

- Patterned, meaning that people in a society live and think in ways forming definite, repeating patterns;

- Changeable, through social interactions between people and groups;

- Arbitrary, meaning that Soldiers and Marines should make no assumptions regarding what society considers right and wrong, good and bad.

- Internalized, in the sense that it is habitual, taken for granted, and perceived as 'natural' by people within the society." 14

Put simply, the act of enlisting in the armed forces implies the subordination of one's private life to the military lifestyle. A great deal of time and effort is necessary to become a soldier, non-commissioned officer, or officer. The army is a very successful organization that creates soldiers suitable for the state's demanding and specific needs. From the very beginning, individuals become part of a culture in which individualism is suppressed, the performance of tasks and missions has priority over personal problems and desires, and sacrifice for higher goals is part of everyday life. The most important aspect for maintaining continuity in a culture (including the military) is tradition, where selected features of learned behavior and action are passed on from earlier generations. When a civilian changes jobs and goes to a different workplace, a complete lifestyle change

13 Yet, they are expected to obey in accordance with par. 70 of the Law of Defense. See "Defense Law," Official Gazette, nos. 73/13, 75/15, 27/16 (2013).

14 Counterinsurgency Field Manual 3-24, Marine Corps Warfighting Publication (Washington, DC: Department of the Army, 2006), pp. 3-6, 3-7. 
is not necessary. Depending on the job, the military perspective differs from the civilian in that membership in the army is deemed to be a privilege, and the function of the hierarchical structure is not questioned. Active army personnel must behave in such a way that they do not threaten the credibility and trust of the public; they must perform their duties conscientiously and responsibly, meticulously carrying out all the tasks they are given, and respect the legislation and other norms defining their responsibilities and obligations.

Military organizations are some of the oldest and, traditionally, most prominent organizations of the state. They have a specific work environment that also has precise organizational and work procedures and requirements. Most military personnel work in military facilities ${ }^{15}$ with restricted access and, within which, a feeling of belonging to the military organization is stressed. In contrast to civilians, active military personnel and cadets wear official uniforms, whereby they emphasize their membership of a specific culture. Military organizations require a great deal from their personnel: 24-hour availability, specific work shifts, a strict schedule of daily activities, mandatory reporting to superiors, unconditional respect for deadlines, demanding physical fitness requirements, strictly regulated conduct, prohibition of public appearances, frequent relocation, prohibition of organization of unions etc. For soldiers, non-commissioned officers, and officers, military knowledge and skills are not sufficient; they must be linked together with values such as courage, loyalty, obedience, subordination to the units, and the possession of high moral principles.

Members of the armed forces are aware that their work may be potentially dangerous. All active military personnel is armed and trained to handle weapons and to use protective equipment. During military training, they learn about and master military customs, conduct, values, and ethics, including obeying and following orders, and how to function within the military chain of command, which is crucial for their success. Hofstede points out that those values have positive and negative sides: good-bad, dirty-clean, ugly-beautiful, unnatural-natural, and that differences occur as people think about what the world should be in relation to what they want for themselves. ${ }^{16}$ The relationship towards what they want for themselves in military organizations is secondary since the entire culture of the organization is founded on respect for common values and subordination of oneself to the needs of the organization and the homeland.

If necessary, the army may, legitimately, use force to execute the tasks it is given. Violent measures are dangerous; therefore, the individual's subordination to the group is required. This entails the readiness to sacrifice oneself for others and, in extreme cases, to give one's life. Lergo points out that the culture of mil-

15 Military facilities are barracks, warehouses, training grounds, camps, and shooting ranges. See "Ordinance on Service in the Armed forces of the Republic of Croatia," Official Gazette, no. 91/09 (2009).

16 Geert Hofstede, Cultures and Organizations, Software of the Mind, Intercultural Cooperation and its Importance for Survival (London: Harper Collins, 1994). 
itary organizations influences what may happen but may also cause the escalation of future events. ${ }^{17}$ Armed forces have a central role in the execution of military operations due to their range of abilities, planning implementation, information processing, operational work, the possibility of maneuver, and the concentration of military power. Consequently, military culture has a crucial effect on the execution of the tasks set. In a military organization, the central elements and cultural values are passed on from generation to generation (e.g., courage, tactical skills, emotional and physical resilience, loyalty to the organization, and decisiveness in realizing the mission received).

Hatch recognized five forms of diversification of subcultures in a large organizational culture - unitary, integrated, slightly, significantly, and disorganized, which is clearly shown in Figure $2 .{ }^{18}$ In the Defense Act, the Republic of Croatia's Armed forces is divided into three branches: the Croatian land army, the Croatian navy, and the Croatian air force and air defense force. ${ }^{19}$ The culture of the Armed forces of the Republic of Croatia is a composite of the culture of the three military branches. Within the Armed forces of the Republic of Croatia, there are different types of combatant units (infantry, aviation and navy) and combat support forces (artillery, anti-aircraft defense, engineers, communications, nu-

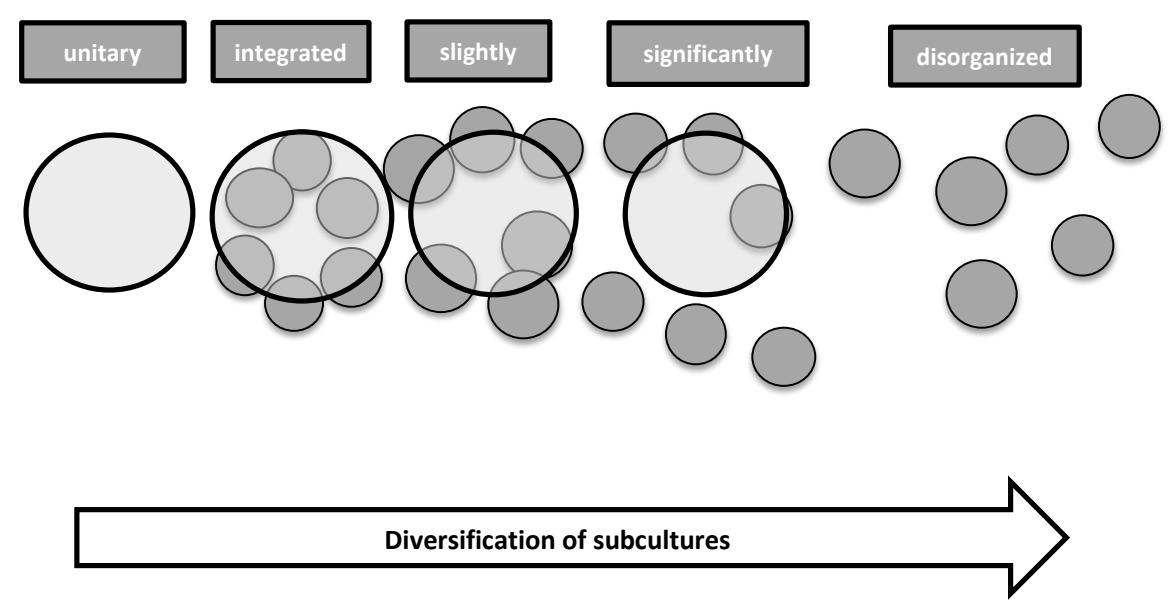

Figure 2: Forms of diversification of subcultures (Source: Hatch, 1997).

17 Jeffrey W. Legro, "Military Culture and Inadvertent Escalation in World War II," International Security 8, no. 4 (Spring 1994): 108-142.

18 Mary Jo Hatch, Organization Theory: Modern, Symbolic, and Postmodern Perspectives (New York: Oxford University Press, 1997).

19 "Defense Law," Official Gazette (2013). 
clear, biological and chemical defense, surveillance and reconnaissance, military police, and military intelligence). The Armed forces of the Republic of Croatia in fact have an integrated form of subculture connections.

If the culture is integrated, the subculture improves its dominant value. The subculture of the branches and services are aligned with the military culture and support and improve it. Figure 3 shows that the military culture consists of the subculture of the branch, and the subculture of the specific services.

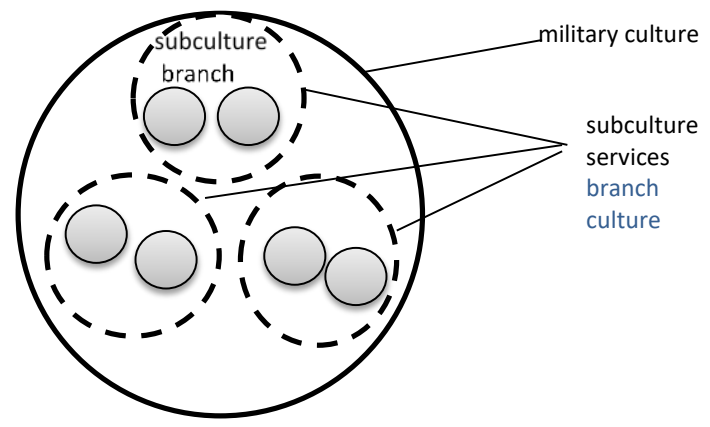

Figure 3: The Subculture Connections in the Military Culture of the Armed Forces of the Republic of Croatia.

All organizations are different, including the military. People are unique because of their distinctive characteristics, but organizational culture provides unity and identity to every organization. Just as no two people in the world are identical, it is also impossible to talk about two identical organizations. Every organization is a living organism: unique, special, and changeable-in a wordalive. Organizations appear, grow, become old, and disappear - they have a life span. An organization's culture dictates how it will react to various challenges. Siegl says that the military culture also consistently shapes how the military views the environment and adapts to meet current and future challenges. ${ }^{20}$ The environment in which military organizations find themselves today is rapidly changing under the influence of globalization, state membership in various associations (military and civilian), and the constant demands for reducing human resources and increasing striking power. As a result, military organizations must change. One of the most important factors in a military organization is the hierarchy and the hierarchical form of management. The peak of the hierarchical pyramid consists of high-ranking officers and generals. The basic system of management of a military organization as a whole is command and supervision. Members of the armed forces wear recognizable military uniforms. Their uni-

20 Michael B. Siegl, "Military Culture and Transformation," Joint Force Quarterly 49, no. 2 (2008): 103-106, p. 103. 
forms reflect a soldier's rank, the member's surname, their specialty, the military school they attended, and their medals. Sparrow further states that military culture usually emphasizes and strengthens discipline, loyalty, and solidarity, which means that it is possible to require additional engagement from each individual in carrying out a given task. ${ }^{21}$ Military culture is passed on from generation to generation and develops as something that is respected and generates pride in service members.

According to Murray, "Military culture may be the most important factor, not only in military effectiveness but also in the processes involved in military innovation, which is essential to preparing military organizations for the next war." 22 He believes that military culture represents the ethos and professional attributes, both in terms of experience and intellectual study, that contribute to a common core understanding of the nature of war within military organizations. The army's existence depends upon the implementation of military operations. It simplifies its operations through standard operating procedures and routines to ensure stability and reduce uncertainty. Rodik-Klarić observed that in professional literature in Croatia, the term "military culture" hardly appears. ${ }^{23}$ The concept of military culture is equivalent to the organizational culture of the armed forces. Kier links the definition of organizational culture with military culture:

... organizational culture is the set of basic presumptions and values that shape shared understanding, and the forms or practices whereby these meanings are expressed, affirmed, and communicated to the members of an organization. Military culture is the attitudes and values that are germane to the military relationships with its external environment, and those values that affect the internal function of the organization. ${ }^{24}$

Hull says that military culture has special features within its organizational culture. ${ }^{25}$ Society's organizational and cultural perspective is valuable for its focus on the forms of knowledge and practices of an organization itself. This includes the army, which has its own historical development and structure of its methods of work, routine, expectations, and fundamental presumptions. An organizational culture also has visible and invisible signs. The visible signs are status symbols (ranks), ceremonies (line-up, inspections), stories, slogans ("Knowledge

21 Robert Sparrow, "Drones, Courage, and Military Culture," Routledge Handbook of Military Ethics, ed. George Lucas (Oxford, UK: Routledge, 2015), 380-393.

22 Williamson Murray, "Does Military Culture Matter?" Orbis 43, no. 1 (Winter 1999): 2742, quote on p. 27.

23 Petra Rodik-Klarić, "On Heuristic Value of the Concept of Military Culture," Polemos 10, no. 2 (2008): 31-48.

24 Elizabeth Kier, "Culture and Military Doctrine: France Between the Wars," International Security 19, no. 4 (Spring 1995): 65-93, quote on pp. 69-70.

25 Isabel V. Hull, Absolute Destruction: Military Culture and the Practices of War in Imperial Germany (New York: Cornell University Press, 2005). 
is Power"), behavior, language, and the style of clothing of employees (uniform). The invisible signs include shared values, beliefs, presumptions, attitudes, and feelings. These signs of the organizational culture form a multi-dimensional concept that presumes various aspects of behavioral lifestyles, which affect the connections and bilateral influence of the various dimensions within the organization. Military culture comprises the values, customs, traditions, and philosophies based on a common recognizable character. Military organizations are specialized for dangerous situations and the use of weapons. Callahan pointed out clearly in his research: "Military culture identifies teamwork in achieving success in battle: discipline, obedience, and loyalty to the hierarchical chain of command as an important military virtue." 26

Military culture is formed by the national culture and factors such as the geopolitical position and historical experience that influenced the national army. Honor, integrity, courage, and strength are central to military culture and have a major influence on every aspect of its cultural identity. Military culture is the foundation on which other factors are built, which generates permanent growth. What differentiates organizations from one another are their broad and unique features. Military organizations are run on a strictly hierarchical basis, in line with their own internal organization and culture. In order to function and for their employees to execute given tasks, the organizations are structured on the basis of the principles of centralization and authority, rely on the integrity, morality, and patriotism of their members, and require behavior based on anti-individualistic and anti-market ideologies. Pielmus asserts that the most important principles and key elements that affect military organizations are based on (1) the rational and formal structure of the organization; (2) strict centralization and united command; (3) conformism and discipline; (4) strong social supervision; (5) maintenance and survival of traditional values and practice specific for an officer's career; and (6) integration potential. ${ }^{27}$

Military culture is unique in its fundamental values, organizational structure, and terminology. Each individual's military cultural identity enhances the bonds between the members and aligns with the organization's rules, policies, and procedures. From the beginning of their education, military personnel accepts the principles on which the military organization and its culture rest. Military education is also clearly defined for each member of the organization, including teachers and students. Their duties and responsibilities are clearly established along with their attitudes towards authority. The military organization acts according

26 Philip D. Callahan, "The Code of the Warrior, The Kinder, Gentler Military and Marksmanship: Changing a Culture," USAWC Strategy Research Project (Carlisle Barracks, PA: U.S. Army War College, 2002), p. 3.

27 Crisitina Pielmus, "Between Two Cultures: From the Military Culture to University Culture. Conclusions on the Organisation for Police Officers' Initial Training," Revista Academiei Fortelor Terestre 4, no. 72 (2013): 374-382. 
to the rules, decisions, and orders, which legislation officially prescribes to regulate its life and work.

\section{Types of Military Schools in the Croatian Defense Academy}

According to the Strategic Defense Review, the Croatian Defense Academy will be transformed into an institution of higher education aligned with the regulations governing higher education and scientific work in the Republic of Croatia, and in line with the processes of the Bologna Declaration and the efforts of NATO for application of the highest academic standards in the field of military education. ${ }^{28}$ The Long-term Development Plan of the Armed Forces of the Republic of Croatia $^{29}$ states that the Croatian Defense Academy will provide the requisite education to meet the armed forces' needs and conduct scientific research. The organizational units will be divided into: Command, Deanery, the Petar Zrinski Military School Centre, the Janko Bobetko Centre for Defense and Strategic Studies, the Katarina Zrinska Centre for Foreign Languages, and the Croatian Army Hall. The Petar Zrinski Military School Centre will include Viceroy Josip Jelačić War College, the Blago Zadro Inter-branch Military Staff College, and the Andrija Matijaš Pauk Officers' School (Cadet Battalion, Basic Officer Education Company, and the Advanced Officer Education Company) and the Damir Tomljanović Gavran Non-commissioned Officer School.

Presently, the University of Zagreb and the Dr. Franjo Tuđman Croatian Defense Academy participate jointly in the undergraduate university study program of Military Leadership and Management, Military Engineering, and Aeronautics. The University of Split and the Dr. Franjo Tuđman Croatian Defence Academy cooperate in the Military maritime graduate university study program

A brief description of the tasks and basic characteristics of each of the schools that comprise the Military School Centre follows.

\section{Damir Tomljanović Gavran Non-commissioned Officer School}

The mission of the Non-commissioned Officer (NCO) School is to educate NCOs to meet the requirements of the Armed Forces of the Republic of Croatia. Its curriculum covers four levels: a course to develop basic leadership skills, NCO training, advanced NCO training, and high NCO training. In September 2015, it was named after Damir Tomljanović Gavran, the Homeland War hero.

\section{Andrija Matijaš Pauk Officer School}

The Officer School provides first and second level education for officers in the armed forces. In September 2015, it was named after the Homeland War hero, Andrija Matijaš Pauk. The first level of education is basic officer training for candidates who have completed military and civilian education for their initial duties as officers, and lower command and staff duties within the branches of the

28 "Strategic Defense Review," Official Gazette, no. 101/13 (2013).

29 "Long-term Plan for the Development of the Armed Forces of the Republic of Croatia for the period from 2015 to 2024," Official Gazette, no. 151/14 (2014). 
armed forces. The ten-month course is conducted at the Croatian Defense Academy and in units of the armed forces. Upon successful completion, students are awarded their first rank as officers (lieutenant).

The second level is advanced officer training. It lasts six months and is also conducted at the Croatian Defense Academy and in the armed forces' units. The course trains officers in the ranks of junior lieutenant and lieutenant. The second level of officer training is also the last level of branch education.

Apart from officer education, there is also a cadet battalion within the Officer School. Its task is to participate in the preparation and implementation of the military training of cadets during the academic year of undergraduate military study courses. As part of the training, three military camps are organized to teach the necessary knowledge and skills which are important for attending the basic officer training.

\section{Blago Zadro Inter-branch Military Staff College}

The Blago Zadro Inter-branch Military Staff College is the third level of education for officers in the armed forces. It lasts ten months and provides the knowledge and skills needed to plan, command, and manage wartime and peacetime operations in national and multinational commands, military staff, and battlefield operations. Officers acquire knowledge important for understanding the inter-relational elements of national powers and their effect on military activities in peace and war. They are trained to master the basic elements of joint warfare, the application of the principles of allied forces and the theoretical basis of joint warfare, for the discharge of all types of duties in joint tactical units in different brigades, execution of the functional duties of a staff officer in branch commands and staff, and preparation and implementation of peace-keeping operations. Apart from members of the Armed Forces of the Republic of Croatia, foreign officers also attend the Inter-branch Military Staff College.

\section{Viceroy Josip Jelačić War College}

The War College is the fourth and highest level of education for officers in the Armed Forces of the Republic of Croatia. It lasts for ten months. Its mission is to train officers for the strategic level of command and higher staff duties. It covers four areas: security, defense management, national military strategy, and warfare skills. To meet the requirements for promotion to the rank of Brigadier General/ Commodore, an officer must complete this course. After completing a war college education, officers are appointed to the highest duties in the field of national security and defense. Students are high-ranking officers in the Armed Forces of the Republic of Croatia, employees of bodies of state administration of the Republic of Croatia, and members of foreign armed forces. The faculty include professors, scientists, military and civilian officials from this country and abroad. Presidents of the Republic, the Parliament, and the Government, as well as other high-ranking officials, provide lectures to the War College. 


\section{Military Engineering Undergraduate and Graduate University Program}

The Military Engineering undergraduate and graduate university study program is an interdisciplinary program. It includes various fields of protection, rescue, and assistance to civilians and institutions in crisis situations, as well as natural and/or man-made disasters. Military engineers acquire competencies in accordance with international and NATO standards and range from modernization, maintenance and overhaul of combat systems, weapons, fire suppression systems and equipment, vessels, and aircraft. The Military Engineering study program enables students to acquire competencies in Croatian and in a foreign language. $^{30}$

\section{Military Leadership and Management Undergraduate and Graduate University Study Program}

The Military Leadership and Management undergraduate and graduate university study program is an interdisciplinary program. It is the first study program of this kind initiated in the Republic of Croatia, making it unique on the labor market in the public sector, especially in the fields of defense and the armed forces, protection and rescue of people and assets, civil and institutions' assistance in various situations such as crisis and disasters. The Military Leadership and Management study program develops competencies which are in accordance with international and NATO standards. ${ }^{31}$

\section{Aeronautics Study Program}

The aeronautics study program began at the Faculty of Transport and Traffic Sciences in the University of Zagreb in 1992. It provides continuity in higher education for military officers such as future Croatian Air Force pilots. This program is important to the Air Force in retaining highly educated personnel. ${ }^{32}$

\section{Military Maritime Study Program}

The military maritime study program is a five-year integrated undergraduate and graduate university study program designed to educate future officers of the Ministry of Defense and the Armed Forces of the Republic of Croatia. The program is designed to provide students with the theoretical and practical knowledge of the professional and scientific principles and procedures relevant to the maritime structure and maritime skills necessary for ship management: navigation, maneuver, maintenance, cargo management and other procedures of regulated international conventions (STCW) and other international and national

30 University of Zagreb, Graduate Study Program in Military Engineering and Military Leadership and Management (Zagreb: University of Zagreb, 2018).

31 University of Zagreb, ECTS Information Package for Academic Year 2016/2017 Course Catalogue - Undergraduate Study (Zagreb: University of Zagreb, 2016).

32 "Become a Military Pilot" (Zagreb: Ministry of Defence of the Republic of Croatia, 2017). 
standards. In addition, the general competencies that cadets complete in the Naval Navigation program are the same as those of all naval colleges. ${ }^{33}$

\section{Culture, Climate, and Relations in Military Schools}

All schools, including military schools, have their own culture, formed by their students, teaching staff, the subjects taught, the types of teaching methods used, the environment, the atmosphere, and all other aspects that affect their value system, beliefs, and feeling of belonging. Kozina points out that only military schools provide the military education necessary for acquiring the competences related to the life and work of officers and non-commissioned officers. ${ }^{34}$ The aspects of acceptance and an encouraging environment presume that the school is a place where prior behaviors are modified and supported, and where completely new forms of behavior are introduced. Every individual in the military education system should have no feeling of rejection, isolation, or inferiority. In other words, the organizations of the school and its climate will have the greatest effect on the students, and also on the teachers who work there. Bruner stressed the role of a school's culture in the creation of a community of teachers and subjects that mutually help one another "(...) through participation, pro-actively, jointly, cooperatively, and dedicated to the construction of significance instead of merely dryly receiving it." 35

Each school's culture may be deemed to be the way of life and work in it, the influence of tradition on its success, and the behavior of students and teachers. The culture of a school, apart from the curriculum, subjects, teaching methods, and technical equipment, also includes all the participants (teachers, students, administration) with their attitudes, understanding, values, and beliefs. A military school is expected to provide military education through acquisition of the knowledge, skills, attitudes, and responsibilities necessary to meet the challenges of a modern, complex world.

A school's culture affects the way classes are run and the work of the teachers themselves. The overall impression a school leaves, whether positive or negative, affects its cultural potential. The culture of a school is created from a blend of the convictions, customs, and attitudes of all its members and its operating environment. The feeling of belonging is intensified when the student is outside the school. An individual identifies with their school as their own organization, which makes them stronger, because they are not representing themselves, but the organization. For example, at West Point (the American Military Academy

33 University of Split, Integrated Undergraduate and Graduate University Study Directions: Military Nautical and Military Marine Engineering (Split, HR: University of Split, 2018).

34 Andrija Kozina, "Professional Military Education: Challenges Facing the Croatian Armed Forces," Strategos 2, no. 1 (2018): 119-136.

35 Jerome Bruner, The Culture of Education (Zagreb: Educa, 2000), quote on p. 93. 
for the Army), these military values are clearly defined and inculcated by all the cadets:

- "Loyalty. Bear true faith and allegiance to the U.S. Constitution, the Army, your unit, and other Soldiers.

- Duty. Fulfil your obligations. Doing your duty means more than carrying out your assigned tasks. Duty means being able to accomplish tasks as part of a team.

- Respect. Treat people as they should be treated. In the Soldier's Code, we pledge to "treat others with dignity and respect while expecting others to do the same."

- Selfless Service. Put the welfare of the nation, the Army and your subordinates before your own. Selfless service is larger than just one person. In serving your country, you are doing your duty loyally without thought of recognition or gain.

- Honor. Live up to Army values. Honor is a matter of carrying out, acting, and living the values of respect, duty, loyalty, selfless service, integrity and personal courage in everything you do.

- Integrity. Do what's right, legally and morally. Integrity is a quality you develop by adhering to moral principles.

- Personal Courage. Face fear, danger or adversity (physical or moral)." 36

These military values are general and apply to all soldiers. Respect for them makes it possible to undertake all duties and missions given in line with the current regulations and legislation. In military schools, teamwork and mutual trust are also developed. The teaching outcomes (organization of life and work in an operation, drawing up orders, etc.) must be completed in a limited time, which requires well-coordinated teamwork. This develops mutual trust between team members. In a real wartime situation, individuals never undertake the given tasks alone, but they are carried out together, whether as part of a group, a squad, a platoon, a company, a battalion or a brigade.

A school's culture is greatly affected by the students' courses and their year of education. If the cultural values of a school emphasize autonomy, the teachers must change their established teaching practices and learn new teaching skills. Johnson and co-authors point out that teachers who believe that students' success depends, to a large extent, on the work of the teacher, will themselves not demand cooperation from others. In contrast, teachers who believe that the students' success depends on the work of the entire school are more prepared to seek intensive cooperation from all participants. ${ }^{37}$ Deal and Kennedy clearly rec-

36 "The United States Military Academy Strategic Plan, 2015-2021," USMA Strategic Initiatives (West Point, NY: United States Military Academy, 2015), p. 8.

37 David W. Johnson, Roger T. Johnson, and Edythe Johnson Holubec, Circles of Learning. Cooperation in the Classroom, $6^{\text {th }}$ ed. (Interaction Book Company, 2009). 
ognized two key reasons why a strong school culture improves learning: "First is internal (where teachers and students don't know or understand what is expected of them or/and how their actions are related to school development)." 38 For precisely this reason, school culture ensures internal cohesion and understanding, which makes it easier for teachers to teach and students to learn.

The second reason is external: society judges a school by its perception as well as its results. Internal squabbling, mixed signals, unfavorable stories, and the lack of tangible evidence that a school stands for something special, make it difficult to secure the support of external groups. Deal and Kennedy mention that a school can communicate its identity to outside groups through shared values, rituals and ceremonies, and a supportive informal network. Convictions, messages, values, behavior, traditions, and routines are basic parts of the culture. Schools become the place where different languages, cultures, religions, and world views are acquired and refined. Since there are no identical organizations, so each school is unique. Schools are complex organizations that are joined together into a larger and stronger system. The school organization is a composite of the culture of the military organization and the relationships which predominate within it. When students come to school, they bring their own attitudes, habits, and different ways of thinking with them. All students carry with them their family upbringing, styles of communication, and the cultural and educational characteristics of their childhood and adolescent environment. Thus, the school's culture consists of several subcultures in each student class, and the class subculture consists of the different identities of the individual students. The most significant aspects of the military school culture at the Dr. Franjo Tuđman Croatian Defense Academy include:

- the social climate - including security, acceptance and care, which all students feel, and which must be welcoming;

- the intellectual climate - each class and the school atmosphere support and encourage the students to make additional effort;

- rules and instructions - all participants are responsible for achieving high standards of study and behavior;

- customs and routines that must be accepted by all participants;

- organizational structure - enables joint responsibility for decision making and problem-solving, which affects the school environment and the actual implementation of life and work;

- $\quad$ partnership and cooperation - effective cooperation with educational institutions, business entities, and social organizations which support the work of the military school;

38 Terrence E. Deal and Allan A. Kennedy, "Culture and School Performance, Educational Leadership," The Journal of the Association for Supervision and Curriculum Development 40, no. 5 (1993): 14-16, quote on p. 15. 
- clearly defined standards in relationships and behavior that help to create a professional culture, excellence, and recognizable ethics;

- wearing uniforms, ranks, and symbols - to ease communication and strengthen the esprit de corps;

- the division of students into troops (squad, platoon, company, battalion, brigade) - strengthens the feeling of belonging to a group;

- official annual evaluation of each staff member - increases the quality of execution of the tasks given because everyone is aware that their work is being monitored and evaluated;

- ceremonies marking important days in the school's history - develops awareness amongst students of respect for tradition;

- public announcement of awards and recognition - pointing out deserving and commendable members of the organization;

- emphasis on duty and service in lecture theaters and troops - learning to lead a unit, run exercise activities and procedures, filing reports, etc.

The culture of a school (especially a military one) differs from the cultural setting of the students' previous educational experience (their family culture, society, religious institution, etc.). They come to the school with their civilian culture, and part of that culture merges with the school's culture. It is easier to identify with a military school culture if it has similarities to their home culture. Hudley and Gottfried emphasize that the teacher must always think about the fact that: "(...) the students' home cultures are different from the school culture and the students' families have different ideas about how their children should be taught." 39

\section{Conclusion}

Schools are not merely buildings, classrooms, and the people in them; they are complex systems. Each part is linked to and dependent on the others, and changes to one area cause changes to the others. This complex concept cannot be placed within a firm framework, but it is necessary to define it as precisely as possible. A school does not exist in isolation; it lives within the environment and social order of its location.

Military school culture is unique and, therefore, a special challenge to students. The army and military schools are included in all spheres of the life of students and affect the everyday lifestyle of their families. In a military school, the specific behavior of the students, brought from their families and civilian life, is modified, supported, and changed into a new form, which is acceptable to the culture of the military school. It constantly affects relationships, expectations, and behavior amongst teachers, administrative staff, students, and the environ-

39 Cynthia Hudley and Adele E. Gottfried, eds., Academic Motivation and the Culture of School in Childhood and Adolescence (New York: Oxford University Press, 2008), quote on p. 129. 
ment. The Dr. Franjo Tuđman Croatian Defense Academy is expected to provide military education for students and cadets in the form of the acquisition of the knowledge, skills, attitudes, and responsibilities necessary for facing the challenges of the modern world and complex wartime operations. Mutual trust is developed between students, faculty, and staff. In a real wartime situation, individuals never undertake the given task alone, but it is carried out jointly, whether as part of a group, a squad, a platoon, a company, a battalion or a brigade. All the development of a culture is linked to and dependent on others, and changes to one part can cause changes in the others.

As a result, the culture of military schools must develop and maintain positivity and the professional development of all participants. The subculture of the class has a major influence on the culture of military schools, as an internal influence, and the culture of the wider society as an external influence. Alongside a strong positive culture, which supports the professional development of teachers and the independent student learning, military schools must become places where teachers are developed professionally and every student acquires and strengthens the competences they need in life and in their military profession. Military school culture, as assessed at the Dr. Franjo Tuđman Croatian Defense Academy, differs in terms of the students' life and work in terms of the social climate, the intellectual climate in the school, the rules, and instructions that regulate school work, the different organizational structures of the commands, and other aspects, such as how ceremonies, official assessment, and service are conducted, in fact, in everything that makes a military school distinctive and special.

\section{Disclaimer}

The views expressed are solely those of the author and do not represent official views of the PfP Consortium of Defense Academies and Security Studies Institutes, participating organizations, or the Consortium's editors.

\section{Acknowledgment}

Connections: The Quarterly Journal, Vol. 18, 2019 is supported by the United States government.

\section{About the Author}

Colonel Andrija Kozina holds a PhD degree in the social field of pedagogy at the Dr. Franjo Tuđman Military Defense Academy, University of Zagreb, receiving the Magna Cum Laude certificate for outstanding achievements during his doctoral studies. His major fields include andragogy, military pedagogy, and contemporary teaching methods. His secondary field is the intercultural curriculum in the military. He is actively involved in popularizing the profession by issuing technical and scientific papers. Currently, he works as a Military Pedagogy and Contemporary military concepts course associate at the University of Zagreb. He is a permanent member of the DEEP team. His current position is Dean in the Croatian Defense Academy. http://orcid.org/0000-0002-3023-2887 